\title{
THE KUMULIPO
}





\title{
THE K U M U L I P O A Hawaiian Creation Chant
}

\author{
translated and edited with commentary by \\ MARTHA WARREN BECKWITH \\ with a new foreword by \\ Katharine Luomala
}

The University Press of Hawaii

Honolulu 1972 
Facsimile reproduction of first edition, published in $195 \mathrm{I}$ by The University of Cbicago Press

Copyright 1951 by The University of Chicago

Foreword copyright $\left(197^{2}\right.$ by The University Press of Hawaii All rights reserved

Library of Congress Catalog Card Number 79-188978

ISBN 0-8248-0201-2

Manufactured in the United States of America 
To the memory of ANNIE M. ALEXANDER

Lifelong Friend and Comrade from early days in Hawaii

Whose generous sponsorship has made the author's research possible 
